\title{
Legal battle threatens universities' use of patented technologies
}

Duke University researchers have been asked to review their use of patented research technologies and use alternative approaches wherever possible. An ongoing legal battle between the university and a former researcher could trigger similar reviews at other institutions.

For more than 100 years, US scientists have used proprietary reagents, devices and techniques under an 'experimental exemption' to patent laws. But this summer, the US Supreme Court declined to review a lower court decision in Madey vs. Duke, which challenged the university's use of former faculty member John M.J. Madey's free-electron laser. As a result, it is questionable whether the exemption will protect scientists against patent infringement liability.

Following the Supreme Court decision, Duke Medical Center Dean R. Sanders
Williams sent a memo to researchers advising them to purchase reagents, devices and kits from commercial suppliers who have acquired the appropriate licenses. The memo was meant to inform researchers how the ongoing legal battle may affect them, Williams says.

"At this point, we have not used central authority to mandate any sweeping changes," says Williams. "We have not asked them to undo any experimental programs that are in progress."

Outside Duke, most universities are taking a wait-and-see approach as the case continues to move through the courts, but some are extremely worried about liability, says Peter Ludwig, a New York City patent lawyer who has been following the case.

"I can't help but come away with the deer-inthe-headlights analogy," says Ludwig. "This hit them like a ton of bricks. It's a difficult problem to wrestle with and they don't know which way to go."

Others say the ruling came as no surprise.

"From everything I had ever read on the 'research exemption', that exemption was very, very narrow - and we never relied on it," says Lita Nelson, director of the Massachusetts Institute of Technology's technology licensing office. "The ruling did not change our understanding of the law."

Ludwig says it's possible industry will back away from the legal battles and the bad blood that would come with demanding licensing fees from universities.

"Maybe it will just blow over and go away," he says. "[But] I think it's only a question of time before someone is going to make a claim against an institution and say, 'You've been using our technology and we want you to pay us."

Tinker Ready, Boston

\section{The refrain in Spain is that Barbacid is to blame}

Oncologist Mariano Barbacid is having his worst year since he returned home in 1998. After repeatedly clashing with health officials over funding for the Spanish National Cancer Center (CNIO) - of which he is director-he is facing the resignation of two prominent $\mathrm{CNIO}$ researchers.

In an e-mail sent on 7 November to CNIO staff, Luis Serrano resigned as head of the CNIO's structural and computational biology program, complaining of Barbacid's "abuses of authority," "excessive hierarchization" and "narrow scientific vision."

Serrano, who heads a similar program at the Heidelberg-based European Molecular Biology Laboratory, devoted $25 \%$ of his time to the $\mathrm{CNIO}$ and was expected to move to the $\mathrm{CNIO}$ full time in September 2004.

Barbacid may be a good scientist, Serrano later told Nature Medicine in an interview, but as a manager, "he's a disaster." Part of the problem, Serrano adds, is that few people in leadership positions at the CNIO have led a research group abroad.

"I have an autocratic style," Barbacid admits. But he says Serrano is "immature" and that his "virulent" letter was prompted by his ambition to be the next director of the CNIO.

During his time at the US National Cancer Institute, Barbacid established a research group that was one of three in 1982 to isolate a human oncogene. Fifteen years later, as vice president of Oncology Drug Discovery at Bristol-Myers
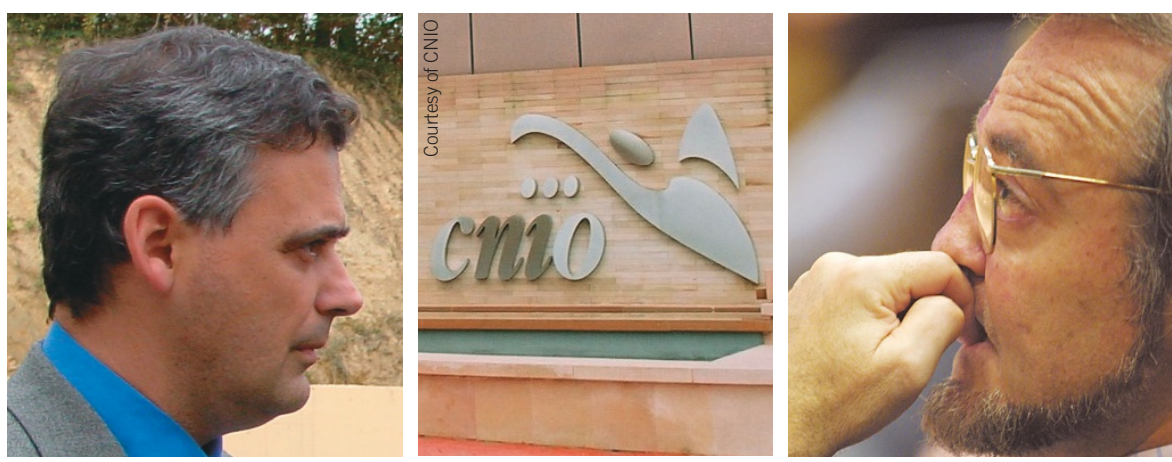

Spanish spat: Calling director Mariano Barbacid (R) a "disaster," Luis Serrano (L) has resigned his post at the Spanish National Cancer Center.

Squibb, Barbacid was approached by the Spanish health ministry to lead the CNIO.

Barbacid's personality has led to several clashes with both policy makers and scientists in Spain. His complaints in the national press about money for the CNIO have annoyed government officials who, he says, have blacklisted him for research grants. Health ministry officials declined to comment. Still, the CNIO has in the last four years obtained several grants from the science ministry and the European Commission.

Several people at the CNIO, who asked not to be named, agree with Serrano's criticisms. But Pere Puigdomenech, director of the Barcelonabased Institute of Molecular Biology, backs Barbacid. "It's normal that CNIO's quality output is still scarce since it's not been [much] time," says Puigdomenech.

In 2003, Spain published 14 life sciences papers in Nature, Science and Cell; 4 came from Barbacid's group. Barbacid says he was considering leaving the directorship because of "burnout." After a meeting on 10 December of the CNIO board, however, health minister Ana Pastor has confirmed that Barbacid will continue in the position.

In the meantime, after a "long and painful reflection," cell division expert Isabelle Vernos, Serrano's wife, who was to lead a research group in the CNIO's Oncology Molecular Programme, has also announced her resignation. "My decision is strictly independent of [Serrano's]," Vernos says.

Xavier Bosch, Barcelona 